\title{
Defining and living out the interior: the 'modern' apartment and the 'urban' housewife in Turkey during the 1950s and 1960s
}

\author{
Meltem Ö. Gürel* \\ Bilkent University, Faculty of Art, Design \& Architecture, 06800 Bilkent, Ankara, Turkey
}

This study investigates the interaction of women's gendered identities and performances in the modern middle strata with the new apartment, while complicating the boundary between the legitimizing discourses of modern architecture and ideas around femininity, during the 1950s and 1960s in Turkey. It conceptualizes domestic premises as the inhabitant's space, where gender roles are formed and performed. Drawing on research concerning the postwar construction of women's identities and diverse ideas of feminine space in a global context, I examine how the apartment was a place for women, who were conceptualized as Western and happy housewives amid Cold War geopolitics. The study ponders ways in which women negotiated/subverted conflicting expectations of the modern housewife. The apartment mediated powerful discourses on structures of patriarchy and identities, while simultaneously allowing women to define and live out the modern domicile as active agents. It embodied the intermediate space between the concepts of modern and traditional, Western and nonWestern, urban and rural, and masculine and feminine.

Keywords: housewife; domestic space; performativity; modern architecture; apartment; Turkey

During the 1950s and 1960s, powerful images of women as stylish homemakers spread throughout the Cold War regions, where capitalism was promoted for combating the perils of communism. These images reinforced the concept of home as a comfortable space for women to operate in as housewives. To a great extent, the modern middle- and upper income groups in major Turkish cities considered such a home to be a contemporary concrete slab apartment. As was the case in different political regimes worldwide, multistorey residential buildings distinguished by plain aesthetics indicated the postwar industrial world. How did 'the apartment', as such, work for women? How did ideas of being modern operate around a woman's identity and her living space? What concepts did the apartment embody in relation to dominant architectural trends and how did these compare to contemporary women's actual experiences inside their spaces?

In this historical context, this study investigates women's experiences and the production of gendered identities in relation to the new apartment, while complicating the boundary between the legitimizing discourses of modern architecture and ideas around femininity. Conceptualizing domestic space as a domain that exemplifies gender as something socially constructed, I investigate the position of the housewife in the modern middle strata both inside 'the apartment' and within society at large, in a global context. This position defines performances, i.e. the acting out of subjects, and embodies Judith

*Email: mogurel@bilkent.edu.tr 
Butler's notion of performativity, which suggests that identities are produced through a multiplicity of acts in response to discourses, which control their subjects while producing them (Butler 1990, 1993). This theorization suggests that the incompleteness of these acts in reproducing their citation embodies a capacity for subversion. In addressing architectural assumptions, I analyze the interior as the inhabitant's space that drapes over the physical space and symbolically makes use of its objects (Lefebvre 1991, 38-39). My analysis draws on research concerning the postwar construction of women's identities. It pertains to diverse ideas of feminine space and women's spatial experiences ${ }^{1}$ and delves into the building of the modern domestic space in relation to traditional expectations. Simultaneously, it explores the fluidity between the binaries of modern/traditional, nonWestern/Western and masculine/feminine. Sources include popular magazines, advertisements, architectural journals, extant buildings, movies and informal interviews - with 14 housewives (and their husbands, in a few cases) as well as with five prominent architects who contributed to the production of modern apartments. Because the apartment, during this period, became a major building type for the middle and upper middle class in the major metropolitan areas, the study focuses on this user group in Istanbul, Ankara and Izmir, where most of the construction of apartments occurred. ${ }^{2}$ This is a nebulous group interrelated in terms of cultural background, education and lifestyle regardless of income (Kuyaş 1982).

Multi-storey apartment buildings were not new to urban Turkish dwellers in the midtwentieth century. Structures from the 1930s and 1940s were plentiful in metropolitan areas. In cosmopolitan cities and especially in Istanbul, nineteenth and early twentieth century apartments of eclectic styles were also intact. However, throughout the 1950s and 1960s, apartment production increased with the enactment of legislation that allowed for ownership of units; finally, the Flat Ownership Law of 1965 allowed individual ownership of apartments. This led to the repetitive output of this building type as a profitable enterprise, thus prompting a build-sell system in the following decades. ${ }^{3}$ The increase in apartment production enabled the development of the middle classes by providing economic housing solutions (Kiray 1982; Tekeli 1984) in the nation's overpopulated major cities. To many, the apartment signified modern living.

The 1950s and 1960s apartment buildings were largely characterized by multi-storey, rectangular masses with large windows and unadorned facades. Plans were primarily intended for nuclear families. Advertisements, such as the ones for prize housing, adapted these apartments for housewives (Figure 1). Contemporary Turkish architects and builders were among those who embraced and rationalized modern apartments as integral to urbanization, modernization, Westernization, development, hygienic living conditions and economy, as well as to higher living standards and social status. The conceptualization of buildings as such can be connected to the legitimizing discourses of architectural modernism, which propagated the unadorned look as an index of civilization. This idea and the declaration of architecture and interior design as undecorated enterprises can be amply found in Le Corbusier's influential book, Towards a New Architecture (1923, 143):

Decoration is of a sensorial and elementary order, as is colour, and is suited to simple races, peasants and savages. Harmony and proportion indicate the intellectual faculties and arrest the man of culture. The peasant loves ornament and decorates his walls. The civilized man wears a well-cut suit and is the owner of easel pictures and books.

Throughout the 1930s, such views were influential within Turkish architectural culture, which claimed to modernize the Republic (founded in 1923), following the termination of the Ottoman Empire. Aesthetic precepts of architectural modernism were readopted as 


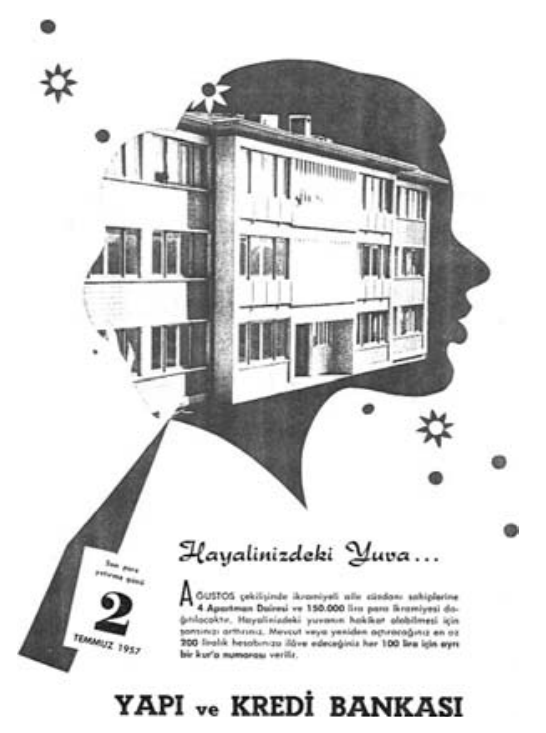

Figure 1. Advertisement for prize apartments by Yapı Kredi Bank. 'Home of your dreams' read the title, appropriating the apartment for the modern nuclear family and the housewife in the urban context.

Source: Hayat, 28 June 1957.

chic design in the second half of the 1950s. Multi-storey housing blocks undertaken by the Emlak Kredi Bank, which had been established by the state to produce housing and to provide credit-based sales, manifested the modernist influence. These buildings, such as the apartment blocks on Atatürk Bulvarı (1957), the Fourth Levent Development (1956-60), the Ataköy Development Phase I (1957-62) and Phase II (1959-64) in Istanbul, and the Emlak Kredi Bank Apartments in Ankara (1957-64) and in Izmir (1956-59), were originally intended for the middle-income groups.

In addition to such examples, many apartment buildings (built privately or as housing cooperatives) reflected the aesthetic precepts of modern architecture, distinguished by large glazed surfaces, unadorned aesthetics, balconies, reinforced concrete load-bearing systems, flat roof terraces, combined living/dining areas and built-in storage units. Their aesthetic vocabulary indicated architects' search for modernity through formal qualities. Arguably, these qualities had ties with the discourse on modernism, which promoted the eminence of a 'masculine' spatial and aesthetic prescription, which was assumed to be better than what were considered feminine characteristics (Wigley 1993, 1995, 1998; McLeod 1994; Sparke 1995; Sanders 2002; Heynen 2005). We might ask, however, how was the apartment, connected to such ideals, a place for contemporary women who were conceptualized as Western 'happy housewives' in the post-World War II era?

\section{The unity of women and domestic space}

The word 'housewife' displays the connection of women to domestic space, as does its Turkish equal, ev kadını. Combining the notions of 'house' and 'wife', and similarly, in Turkish $e v$ (house) and kadın (woman), the notion of housewife (ev kadını) denotes domestic space as an extension of a woman's identity. Her link to the contemporary apartment embodies this assumption, as do concepts related to her position in the Western 
context, post-World War II. The years following the end of World War II witnessed major political transformations in the world. The United States and the Soviet Union emerged as superpowers espousing the opposing ideologies of capitalism and communism. In this bipolar aftermath of the war, Turkish foreign policy firmly identified its own persona with the West. ${ }^{4}$ The victory of the Democrat Party in the 1950 elections reaffirmed Turkey's stance as a democratic country; it brought liberal parliamentary democracy, closing an era of one-party rule. Turkey's political stance was rooted in a regard for the United States as the epitome of modernization, democracy and wealth.

In the dynamics of Cold War geopolitics, images of women as charming wives, mothers and consumers were disseminated in the United States and in other locations, like Turkey, which recognized it as the embodiment of modernity. These images facilitated the promotion of democratic capitalism internationally. ${ }^{5}$ Home decorating and women's magazines, Hollywood movies, advertisements and television (where available) all played a crucial role in applauding a glamorized feminine culture and in stabilizing this culture within the domestic space as the contemporary way. Betty Friedan (1963) was among the first to problematize this feminine construction in its spatial connection to the postwar American home and to women's experiences inside it. ${ }^{6}$ Viewing the American suburb as the setting for unpaid female labor, Dolores Hayden $(1981,27 ; 1984 ; 2000,267)$ argued that regardless of the housing typology, the conventional home was portrayed as a surreal environment that made housework look like no work at all. Equipped with appliances and detergents, it was promoted as the modern domestic ideal. Evaluating this ideal and the promotion of the postwar feminine culture in its socio-political complexity in France, Kristin Ross $(1995,78)$ suggested that an image of la femme typique denoted women as managers as well as victims, responsible for the hygienic condition of the 1950s home interiors. Clean women suggested clean families and a clean France. Located within the boundaries of the home, as domestic consumers and managers, women operated as shapers of 'everyday life'?

The status of postwar women in connection to the notions of home and nation was crystallized in the Kitchen Debates of 1959 between Richard Nixon, American vicepresident and Nikita Khrushchev, Soviet premier, during the American National Exhibition in Moscow (May 1988, 16; Colomina 1999, 351-352). A model American house equipped with consumer goods was a major attraction of this event. As Elaine Tyler May $(1988,16)$ noted, 'the two leaders did not discuss missiles, bombs or even modes of government. Rather they argued over the relative merits of American and Soviet washing machines, televisions and electric ranges - in what came to be known as the Kitchen Debates amid the Cold War.' The Kitchen Debates exemplified the assumption of the kitchen as a space for women in patriarchal societies. The modern domestic kitchen and its fittings have been important in shaping gender as well as global ideas around modernity (Bennett 2006; Johnson 2006; Saarikangas 2006; Supski 2006; Watkins 2006). For the American leader, the modern home, its kitchen and its appliances constituted a symbol against oppression; it represented social emancipation. Idealizing the suburban home, Nixon (quoted in May 1988, 17) stated,

To us, diversity, the right to choose ... is the most important thing. We don't have one decision made at the top by one government official ... We have many different manufacturers and many different kinds of washing machines so that the housewife has a choice ... Would it not be better to compete in the relative merits of washing machines than in the strength of rockets? [emphasis added]

The domestic premise was not only perceived as a locus for the sexual division of labor, but it was also conceptualized as the most critical social unit around which political ideas 
were centered. Armed with machinery, the home was regarded as a reflection of the greater nation. The modernization and progress of a nation depended on the mechanization of the home - its interior, its kitchen and its fittings. Ideologically, then, the socio-economic welfare of the state depended on the prosperity and health of nuclear families. Associated with domestic appliances, the housewife was tasked with this job.

In Turkey, the American influence was felt in all aspects of daily life, ranging from trade to fashion and entertainment - American music and Hollywood films being the most prominent examples. Hollywood movies were widely shown in major cities and greatly influenced the Turkish film industry; some popular movies were Turkish adaptations of famous Hollywood films. As the interviewees expressed, going to the cinema was the prime source of entertainment, especially for women, before the advent of television at the end of the 1960s. Movies played an important role in creating feminine, modern and socioeconomic identities. Also important was the American impact embodied in other aspects of visual culture, including the promotional posters of businesses such as banks and travel agents, popular magazines and advertisements. This impact was partly due to an overt infusion of aid to the country, including the Marshall Aid, which was structured to provide political stability in postwar Europe. Durable American commodities such as refrigerators and cars dominated the imported goods market. Advertisements for refrigerators, vacuum cleaners and washing machines not only idealized the Western housewife, but also celebrated her identity as a happy, healthy and attractive homemaker, providing the family with a clean and modern domestic space. 'Happiness has entered our house', read a Hoover washing machine advertisement from 1952; it portrayed a content housewife being kissed by her husband on the cheek. 'The washing machine has saved me from the troubles of laundry day', read the subtitle (Figure 2). Washing machines and vacuum cleaners were promoted as 'appropriate for every house and every budget'. However, this was hardly the case. Household appliances were expensive and usually imported goods. ${ }^{8}$ Although sellers offered them in monthly installment plans, they were still only affordable

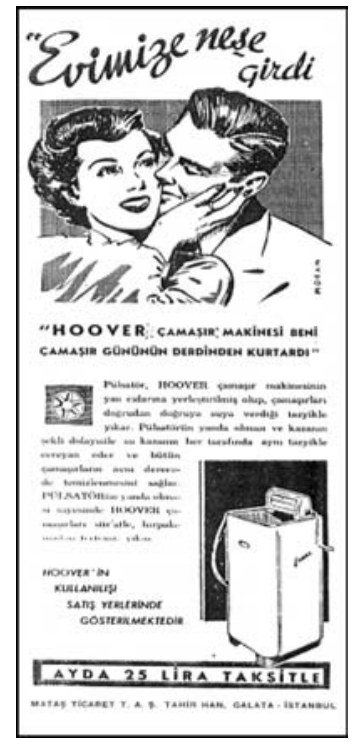

Figure 2. Advertisement for a Hoover washing machine.

Source: Resimli Hayat, May and June 1952. 
to higher income groups who relied on the services of domestic helpers from the lower strata who were available for low wages, as will be discussed.

Such advertisements rated modernization and hygiene in the domestic space against American and European standards. ${ }^{9}$ They also crystallized women's role in representing the nation. 'Turkish women' had represented the modern façade of the nation, since the founding of the Republic; their Western appearance was of utmost importance in separating the new state from the previous Ottoman Empire. The Republican project of modernization emphasized women's equality to men in the public domain, ${ }^{10}$ yet their social role remained mainly unchanged in the private realm; their contribution to modernization suggested 'being housewives a la West' (Arat 1997). As such, the 'modern' Turkish woman reflected the strong alliance of the country with the West, which was predominantly defined as the United States, amid the Cold War dynamics. Although women's roles and responsibilities at home were the same, it is remarkable to observe that the publicity of 1930s Republican women as educated public figures working in the public sphere as pilots, doctors, etc., was largely replaced by a mass of images promoting 'domesticated' women situated in contemporary homes as 'Mrs. Consumer' during the 1950s (Akcan 2001, 115; Ockman 1996, 201).

Yet, the housewife was 'Mrs. Consumer' only to the extent of her social status and economic power within the patriarchal family structure. In 1950s Turkey, women's contribution to production in high-level jobs was still limited. In 1955, only 5.2\% of working women were employed outside of agricultural activities, while this number was $31.3 \%$ for men (Özbay 1990, 120). It was usually considered prestigious for housewives to stay home as homemakers. ${ }^{11}$ This value system, broadly seen in industrialized societies (Young and Willmott 1957; Rainwater, Coleman, and Handel 1959; Komarovsky 1964; Kuyaş 1982, 191), perpetuated a preference for staying home. If there was no substantial financial need, women did not prioritize working or earning money (Çitçi 1974; Ecevit $1990,107)$. Moreover, some women preferred not to work, because this did not change their status at home. On the other hand, it increased their workload: their paid labor accompanied by their unpaid domestic responsibilities. ${ }^{12}$ Accordingly, husbands usually had the financial means and, thus, the authority to make the larger consumer decisions relevant to the house, such as purchasing household appliances and furniture.

The financial power of her husband was a constitutive element of a woman's social status. A housewife could live in a modern apartment with the service of a female domestic helper of a lower stratum. It was assumed that if a woman was married to a well-to-do husband, she lived a comfortable life and could choose not to work. As commonly expressed, she became 'the woman of her house'. ${ }^{13}$ However, women of low income or from the agrarian labor force often had to work in order to support their families. The assumption of womanhood as being married and being a wife and mother was an important theme of popular culture and of Turkish family movies, such as In the Name of Law (Kanun namina, 1952), directed by Akad, The Days that We Made Love (Seviştiğimiz, günler, 1961) and Broken Lives (Kırık hayatlar, 1965) directed by Refiğ. These movies emphasized proper social roles - good and bad, poor and rich, ethical and unethical (Abisel 1984). Undoubtedly, conceptualizing a woman by her connection to the notions of home and husband reduced the development of education for women of the middle strata, and thus the participation by women in the public domain in high-level jobs. However, education was important when it was believed to prepare women for married life and raising children (Criss 1993, 248). The level of education designated the status of a woman as a prospective housewife, mother and consumer. 
The visual materiality of home represented a housewife's persona and competence as a homemaker. It also mirrored her husband's social status and economic power. Moreover, it indicated the inhabitants' modernity and Western socio-cultural identity in the community of the same socio-economic group. These were important incentives for the housewife to attend to a 'proper' appearance of the home. This meant that her performativity, disciplined by powerful discourses, produced social identities and social distinction for her (Butler 1990, 1993). In the context of this social construction, the 'modern Turkish woman' in the mid-twentieth century, like her Western counterpart, represented the family and the nation, on the domestic front. The materiality of the domestic interiors was viewed as an extension of her gendered and modern identity and her social status (Figure 3). Acknowledging the housewife's performance in producing modern interiors, the well-known Turkish architect Sedad H. Eldem $(1973,10)$ wrote that it was through the agency of the young housewives that, 'cultivated and tasteful families wished for a new style in their life and were able to accomplish this'. Housewives were considered leading social actors and amateur decorators, defining the modern domicile.

\section{The housewife and the modern apartment}

The housewife's position in building the modern domicile was amply addressed by Le Corbusier, one of the most prolific figures of modern architecture. His impact on Turkish architectural culture and especially on younger architects and on the development of the modern apartment can be seen in the design of apartment buildings (Figure 4). Le Corbusier's ideas about the modern domicile in relation to the housewife were published in an Arkitekt (1949) article, which was translated by architect Şemsa Demiren with the title, 'Horizontal City, Vertical City'. Here, Le Corbusier portrayed modernist apartment

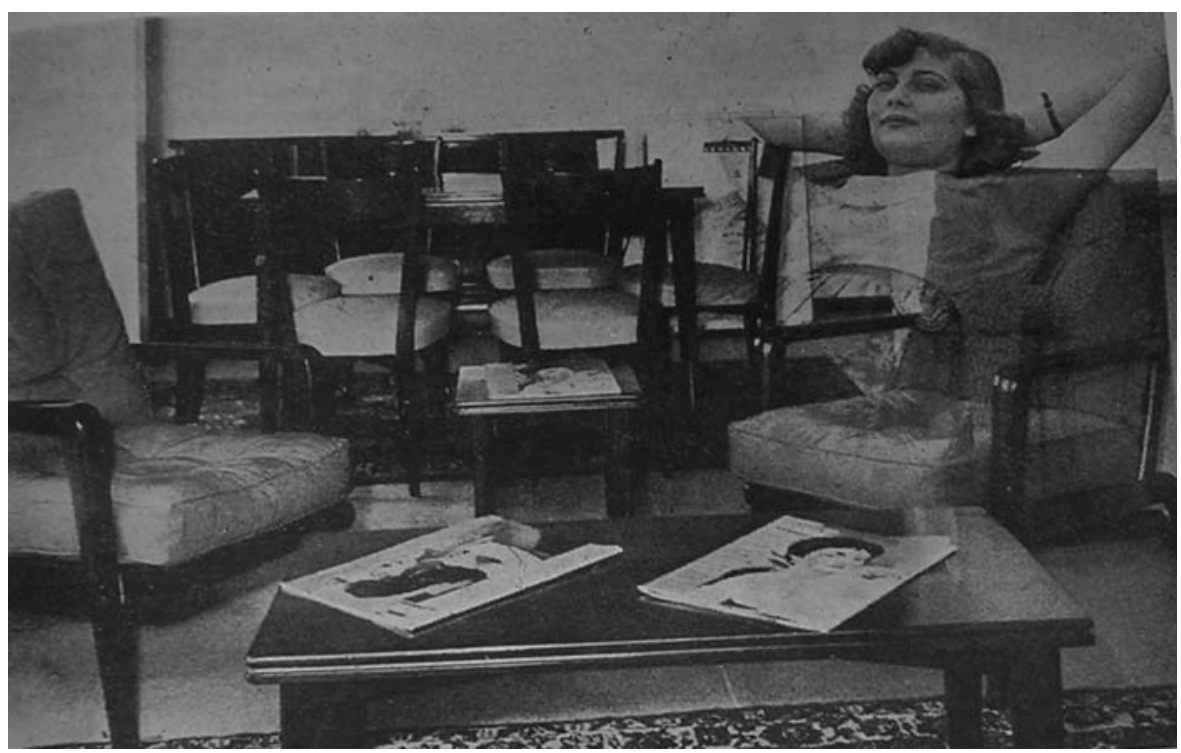

Figure 3. The materiality of domestic interiors was viewed as an extension of women's gendered and modern identities and social status. Subtitles of a prize house promotion in Resimli Hayat reads: "A housewife first of all wants a home that she can call "mine".

Source: Resimli Hayat, July 1954. 


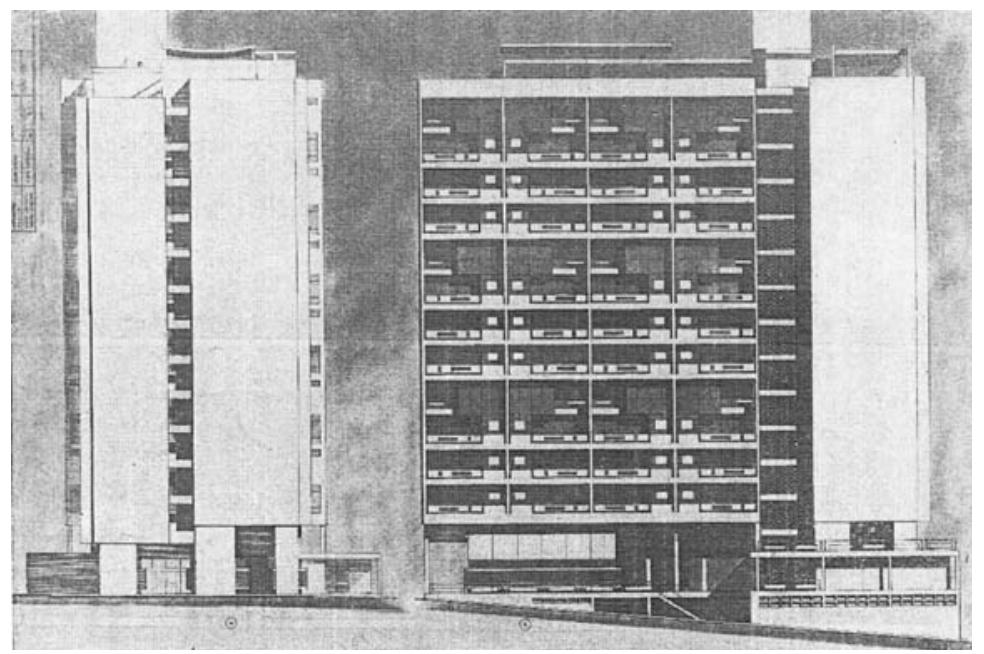

Figure 4. Among the most illustrative manifestations of Le Corbusier's ideas in Turkey was the Hukukçular Apartments (1960-61 by Haluk Baysal and Melih Birsel, Istanbul) embracing the concept of rue interiéure and duplex units.

Source: Arkitekt, 1961, 30, no. 305: 164.

blocks as vertical utopias that the housewife would 'beautify'. He declared, 'Rational spatial organizations have reduced the burden of household drudgery on housewives to a certain extent'. This utopia was equipped with the necessities of everyday domestic life: running hot and cold water; central heating and ventilation; elevators; and communal services such as emergency care, birth and childcare facilities. Le Corbusier's radical designs proposed roof gardens in order for children, in his words, to play and take advantage of clean air and sun. Shops, food and laundry facilities provided everyday needs for the home. Such amenities would give the housewife spare time to take care of her children and to 'beautify her house'. Le Corbusier $(1949,165)$ stated, 'In this orderly and peaceful environment, men would find happiness and the comfort of domestic life.' Embedded in his remarks was the identification of man as the master of the house and woman as its manager. The undecorated apartment, even as it embodied radical domestic ideas, was conceptualized as a masculine space where the housewife performed her assumed social roles.

The longstanding polarity between male mobility and female stasis (Wigley 1991, 334) defined the modern apartment that was a testament to the modernized West in Turkey, during the 1950s, when the country firmly adhered to the Occident as the center of civilization, urbanization and development. Yet, the postwar West redefined and reinforced women's connection to domestic space. The dichotomy between the so-called modern and traditional or Eastern and Western, which had been clearly established concerning women's looks, was fluid in terms of the unity of women and the home. Influential ideas around femininity and space maintained women's secure position in the home: they reinforced the connection between the concepts of 'house' and 'wife' as 'housewife'. Socially, the concept of wife explained the role of a woman in society. Regardless of her working status, she was considered a housewife (Oakley 1976; Kandiyoti 1982; Kuyaş 1982; Özbay 1996). The contemporary Turkish apartment designs, 
appropriated for the modern nuclear family of the middle strata, embodied this assumption.

As Le Corbusier's rhetoric exemplified, a woman was not only in charge of the peace, order, happiness and health of domestic space, but she was also responsible for its decoration or appearance. Yet modern architecture prescribed this appearance as undecorated aesthetics, and it developed as a reaction to what were considered 'feminine' traits. As Hilde Heynen $(2005,3)$ pointed out, architects, including Hermann Muthesius, Adolf Loos and Henry van de Velde, contrasted simplicity and integrity with the effeminate traits of nineteenth century eclecticism at the turn of the twentieth century. According to Mark Wigley $(1993,10)$, modern architecture accorded inferior status to the ideas of 'feminine, domains of ornament, accessories, interior decoration, art nouveau, architect's partner, homosexual, women and so on'. Modernist discourse attempted to transform aesthetic provisions, beliefs, norms and values by proposing that being modern involved a 'masculine' expression. A poster designed for the Dwelling Werkbund Exhibition in Stuttgart (1927) explicitly illustrated the rejection of the Victorian interior that was characterized by 'feminine' traits. ${ }^{14}$ Modern architecture's involvement with the manifestation of masculinity can be observed in Ayn Rand's famous novel The Fountainhead (1943) and in the adapted Hollywood movie shown in Turkey, starting Gary Cooper. Here, the main character, Howard Roark, embodies the masculine image of the modern architect - a hero who would rather destroy his modernist project than allow the client aided by another architect to turn it into an eclectic edifice with decorated façades. ${ }^{15}$

Influential Turkish architects and interior designers promoted modernist aesthetics as domestic ideals throughout the 1930s. In the second half of the 1950s and 1960s, designs for domestic interiors and furniture reflected a preference for the undecorated style (Gürel 2009). This can amply be seen in popular magazines, such as the Beautiful Home section of Hayat and in architectural publications. ${ }^{16}$ The undecorated aesthetics, at times, constituted a point of tension between the modernist architect and the housewife, the other decorator. One housewife, who preferred to decorate her modern apartment in Istanbul with neoclassical furniture and eclectic accessories, explained her efforts to compensate for the emptiness and spaciousness sought by the architects: 'I shopped for a long time ... This apartment is so spacious that it took me a while to fill it up. I kept on buying more and more furniture' [emphasis added].

The eclectic furniture and the ornamental look - enriched with crystal mirrors, tableaus, gilded frames, carton-pierre ceiling medallions, chandeliers, brocade upholstery and Turkish rugs - strongly contrasted with the modern interior architecture of the apartment, which had low ceilings, large glazed surfaces, metal mullions and balcony railings, unadorned walls and the architect's furniture proposal in mid-century modern style. However, such contrast was problematic for modernist architects, who envisioned architecture as 'total design'. Ornamental aesthetics not only worked against this vision, but was also considered anachronistic and 'feminine'. According to a prominent architect of numerous multi-storey apartment cooperatives in Ankara since 1955, housewives often interfered with the architectural unity of modern designs. The well-known architect construed the housewife's relationship with the apartment as follows:

Housewives search for an identity through home decoration ... Especially in apartments, they try to alter the design of interiors to say that 'I did' ... They put adorned furniture, accessories, etc. ... I am a Modernist, that's why I am against it. You know what they say, just like modern clothing has changed, so too has taste. In other words, just like you cannot make Marie Antoinette sit in a modern chair, if you make a modern person sit in a chair that belongs to the age of Marie Antoinette, it looks alien. 
In addition to a modernist architect's aesthetic views and design concerns, these comments indicate the subject position and the power of housewives to redefine apartment interiors. While Turkish middle and upper middle class housewives' aesthetic preferences were far from being homogeneous, they had the power to show their own preferences in creating spaces. Their assumed social role as being largely responsible for the physical condition of the home allowed them to compensate for their secondary status to men in the same social group. Perhaps the most typical example of a housewife's intervention was curtain sets with heavy fabric for privacy at night and tulle to filter the sunlight - these became integral parts of the architecture. The housewife was responsible for their material quality, such as fabric, color and style, as well as their maintenance. She also performed their operation during the daytime and at night to control light and privacy (Kennedy 1999, 89). Women's performances associated with the curtain sets not only (re)defined spatial identities, but they also mediated the conflict between the transparency of modernist aesthetics and the cultural norms for privacy in the home. Curtain sets transformed vast glass surfaces and refigured austere walls as subjective.

Decoration tips published in the popular Resimli Hayat and Hayat magazines exemplify women's appropriated roles as users, amateur decorators and domestic consumers in the absence of decorating magazines in Turkey. They also portray housewives of a certain social stature as liberal figures in control of their surroundings. Like the women's fashions amply published in these magazines, the images of interiors reflect an Occidental taste, indicated by the latest trends in Europe and the United States. However, it would be misleading to think of the new apartment interiors completely as products of an imported Western taste (modern or not) and contemporary middle and upper middle class housewives as consumers contributing to their formation. Rather, the new apartment was a medium through which traditional gender performances blended with contemporary ones. Within the boundaries of her home, a housewife could present herself as a maker of new spaces. The traditional element of the çeyiz (trousseau) was a tool to do this.

\section{The housewife's 'performativity' as maker of spaces in the modern apartment}

According to Turkish custom, the bride is responsible for dressing the marital home with her çeyiz (trousseau), which includes housewares, accessories, household linens and other textiles. In a traditional sense, the çeyiz is the pride of a bride and her family. Its contents are expressions of their cultural formation. In essence, the idea of çeyiz is a means of simultaneously forming and performing gendered identities. The acts of its making (or composing), which can involve the production of household accessories (e.g. sewing and embroidering textiles and knitting lace) and the purchase of household goods, as well as its utilization after marriage, embody performances that form (and transform) identities, social roles and power structures in the domestic space. This idea relates to Judith Butler's $(1990, x v)$ theory of 'performativity' a multiplicity of acts - 'a ritual, which achieves its effects through its naturalization in the context of a body'. As theorized by Butler (1990, 138), 'gender is not a fact, the various acts of gender create the idea of gender, and without those acts, there would be no gender at all'. Gender is a construction, and it is sustained as such through social performances. The çeyiz, in this sense, mediates the formation of a woman's identity as a prospective housewife in charge of the visual quality of her domestic space. Thus, it provides a way of inscribing a housewife's persona in her home. Dressed in the bride's possessions, the marital home becomes an extension of her personality. As such, this traditional element, which sustains its power through reiterative 
acts, marks a subject position for the housewife as a maker of spaces. While allowing her to carve out her personalized space, the performances associated with the çeyiz reiterate and appropriate the traditional patriarchal family structure as well as local ideas and identities about womanhood. These performances also produce the capacity to transform these aspects and women's authority and experiences in the domestic setting in relation to this structure, precisely because reiterative acts have the potential for slippage. This suggests that the individual performances of the çeyiz can change according to different spatial, social, cultural, economic and temporal contexts. Arguably, the housewife's changing role as Mrs. Consumer and improvements of her education, in an urban context, altered the acts involved in making and utilizing her çeyiz, which traditionally included 'chest goods' such as linens, bedspreads, tablecloths and lace. Women's individual performances associated with the çeyiz came to involve elements of contemporary living, such as furniture sets for the dining room and kitchen appliances. This change in individual performances helped women to negotiate the different expectations of being a modern women and a good housewife. Significantly, it empowered women's authority to shape and control their environment and to undo the modernist ambitions/assumptions of architects and builders as well as the associated constructions of gender. The çeyiz served to incapacitate the prescribed aesthetics (e.g. 'masculine' claims of physical expression) and redefined the modern apartment as subjective. In other words, it empowered a housewife's role as an active agent in producing/defining domestic interiors.

The subject position of the housewife can further be explored in social performances and in the specific spaces in which these were acted out. For example, we take the living room - the front stage of the apartment. If the domestic space in general reflected the social status of the family, which was determined by cultural background as well as the (husband's) income and the (housewife's) skills and tastes, as already discussed, the living room was the physical setting that made these aspects visible to others (Ayata 1988). This was where family and friends were entertained. The architectural features of the modern living room, characterized by transparency, spaciousness, combined reception and dining areas, and unadorned aesthetics were conceptualized as the embodiment of modernity. Notably, the modern living room as such did not pre-exist its performances; rather, social and gendered performances brought it into being as a space of modernity (Gregson and Rose 2000). A significant example was the women's reception day (Kabul günü), when a housewife in the middle or upper income level hosted a circle of female friends on a designated day of the month. Depending on the level of income, tea might be served in crystal glasses on silver saucers and pastries might be presented in porcelain dishes. The best of the hostess and the material culture of the home were utilized to produce a distinctive experience. This occasion gave a housewife an opportunity to display her cultural formation and modern merit as much as her active role in shaping her space. The totality of a woman's receiving day, ranging from the visual qualities of the space (i.e. its decoration, order and representation) to the dishware and food, including the presentation, were read as a housewife's persona, which indicated her modernity; this modernity indexed an interpretation of the West. According to Özbay (1990), women's reception days acted as a school of modernization for middle class women. I would add that they also mediated the gender constructions of the modern woman with cultural expectations of appropriate middle class gender performances for women.

These performances expose how identities are produced within the space in which they are acted out (Butler 1990; Sparke 2004, 415). Thus, the modern apartment not only constituted a space in which assumed gendered roles were carried out (i.e. good housewife, good mother, good house manager, good hostess and contemporary/Western citizen), but 
also an arena in which women as active agents, rather than passive figures, performed and lived out their gendered identities.

\section{Women's experiences in the apartment}

In contrast to the traditional house, in which brides were forever guests of their mothers-inlaw, modern apartments were envisioned as places for the nuclear family. Even when older parent(s) had to live with the family, the apartment was appropriated for the housewife. Its interiors provided her an unmarked domain on which to inscribe her identity. As such, women embraced them. For the housewife, an apartment symbolized modernity, because it usually incorporated contemporary equipment and fittings, such as central heating, hot water, electricity and usually elevators when the buildings were higher than three stories. Plans incorporated modernized bathrooms with Western-style apparatus (Gürel 2008) and kitchens with modern equipment. The latter were designed slightly bigger than the 1930s schemes to accommodate refrigerators, which were becoming an important feature of the modern domestic space. The level of luxury and the availability of technology in apartments varied. Middle class apartments could not match the luxury of the upper middle and upper class buildings. Some buildings were poorly built and did not have central heating or elevators to reduce the construction cost. Even so, this building type was associated with more comfortable living conditions and easier maintenance than older single-family houses. ${ }^{17}$

Usually, old houses had several stories and sometimes intermediate levels and nooks; they were difficult to heat and to clean. Recalling a dilemma between choosing to move to a nineteenth century house or to a new apartment in Izmir during the late 1950s, a housewife explained her feelings:

I looked at an old house when we moved to Izmir. It was a beautiful house located next to the sea. It had a wonderful view and beautiful solid wood doors. I liked it a lot. My heart wanted to live in it. But, I preferred to move to an apartment instead because I was tired of housework. I was tired of cold houses, cold bathrooms.

These words echo the opinions of many who were tasked with maintaining the domestic realm. Although old houses, which were sadly torn down to be replaced by apartment buildings, are now remembered nostalgically, they were considered hard to maintain and to live in. ${ }^{18}$ Therefore, many housewives preferred to move to new apartments.

However, one cannot underestimate the shortcomings of apartment interiors. Detached from the earth, the city flats had limited possibility of extension. Storage spaces were often inadequate. This was mainly because of spatial and economic limitations. Many residents enclosed their balconies, later on, to gain space. An architect's wife, who lived in a modernist apartment building, designed by her husband in Ankara towards the end of 1950s, complained, 'male architects often sacrificed functional requirements for aesthetic considerations in domestic designs'. ${ }^{19}$ The difficulty of cleaning the glazed walls was a common complaint among the housewives who lived in this and similar buildings. Notably, such cases exemplified the paradox between the modernist claims to functionalist design and an interest in prescriptive formal and stylistic concerns. ${ }^{20}$

These design characteristics of the modern interiors were managed with the employment of maids. Having a domestic helper was the norm, as is still common practice. The maid acted as a mediator between the modern apartment interiors and an idealized housewife. This is best explained by women, now in their seventies and eighties, who lived in such apartments. As one resident put it, the large glazed surfaces were very enjoyable if someone else cleaned them and washed the curtains covering them. She recalled how her 
domestic assistant complained about maintaining the windows and the curtains. Their cleanliness was a source of pride for the housewife:

Everywhere is glass! My assistant used to say to me, 'I rather have you curse me than tell me to wash the windows and the curtains.' It took forever ... The whiteness of my curtains was famous. People often complimented me.

Such feelings of pride and concern for the cleanliness of the windows are still relevant in Turkish domestic culture, just as apartments are a powerful part of the current urban landscape. The same can be said for the employment of domestic helpers.

An interesting outcome of the use of paid labor was the late entry of cleaning appliances, even to higher-income households. Although imported washing machines and vacuum cleaners were advertised in 1950s magazines and newspapers, these were not widely seen in homes. This was mainly because labor was inexpensive. Interestingly, in some interviews, the housewives could not recall the date when the washing machines were purchased. To a great extent, this was because a washing machine did not always change the housewife's life as dramatically as would be assumed. Women with a certain socio-economic status relied on domestic service for doing the laundry. On the other hand, some husbands remembered this occasion more vividly simply because they made the financial decision to buy such equipment. Surprisingly, in the apartment plans of the 1950s and even of the early 1960s, architects did not usually allocate a space for the washing machine, although they ardently promoted the new interiors as symbols of modernization. Washing machines were either squeezed into the bathrooms or a space was later created by renovations, usually instigated by housewives (Figure 5).

In general, maids were women, because housework was assumed to be a woman's task. Maids could not afford to live in neighborhoods where middle and upper class apartments were built. They lived in low-income neighborhoods and squatter settlements that proliferated as a result of mass migration from rural areas to cities. Postwar attempts to
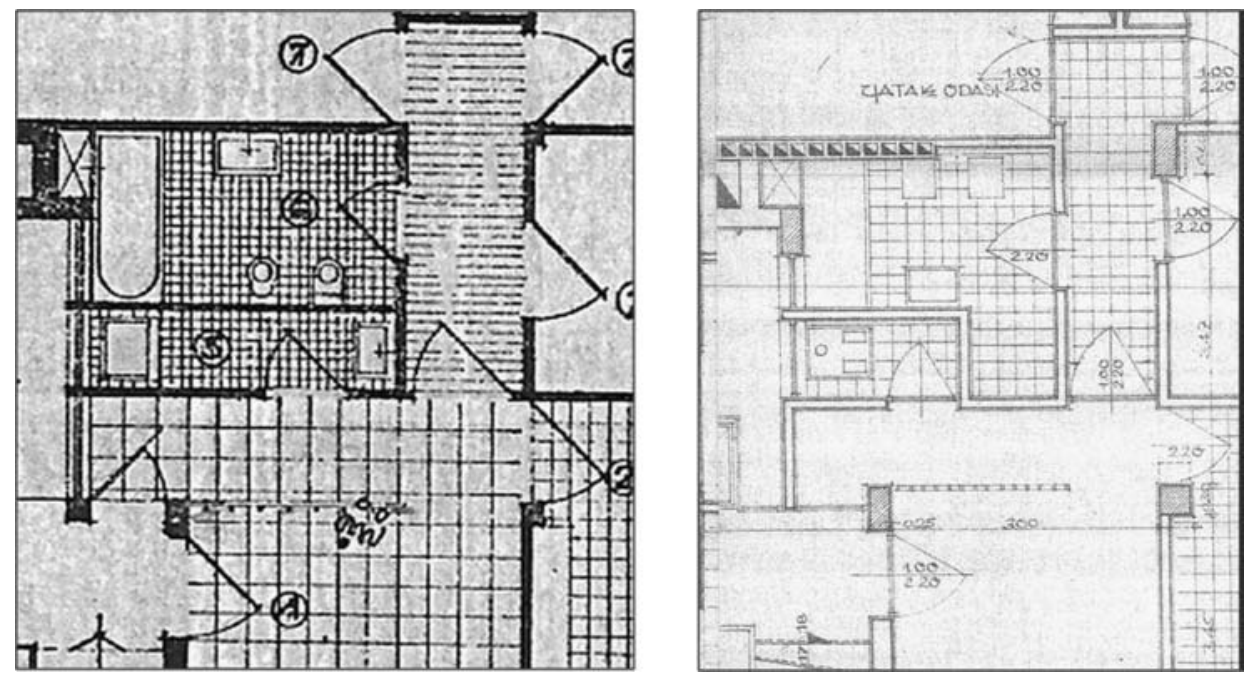

Figure 5. Bathroom plans for the Fuar Apartment, Izmir (1960). Left: The architect's proposal as published in Arkitekt (1961). Right: Changes after a the female client's intervention to accommodate a washing machine.

Source: Left: Arkitekt, 1961, 30, no: 302: 8. Right: Konak Municipality Archives. 
unify a Western alliance against the communist bloc enabled foreign aid to enter the country. While helping industrialization, this disrupted the labor-intensive structure of the rural areas. Because the cities could not absorb the unskilled and uneducated rural masses, these groups became 'marginal' (Şenyap1l1 1996). During the 1950s, the best opportunity for migrant women was to work as maids for middle class women (Kandiyoti 1982, 104). This situation produced an exploitation of labor; the maid worked for low wages, providing services enjoyed by upper income groups. Depending on the socio-economic conditions and need, the maid came on a daily, weekly, biweekly or monthly basis. Some well-off families employed live-in maids. The changing relationship between working class women and middle class housewives in the domestic setting was a form of subversion/negotiation that was due to the uncertainty of citational practices, i.e. their incompleteness in reproducing their citations (Butler 1990, 1993). The maid helped to do the cleaning, the laundry and the cooking. This enabled the housewife to negotiate and perform the patriarchal family dynamics and the expectations of her as a good middle class housewife and modern woman in charge of the production of the modern domicile. When a housewife entertained guests in the reception area, she could perform her modern identity, while the domestic assistant performed traditional gender roles using low technology in the kitchen. When housewives preferred or did not need to participate in professional life, the availability of domestic help gave them more time for leisurely activities in the public domain, such as going to movies and attending social events, including reception days. When women of the middle strata entered professional life, the maid acted as a buffer to absorb the changes in family life, thus sheltering men from changes in the role of the housewife (Kandiyoti 1982, 117).

Managing the domestic space with paid aid not only eased the burden of household drudgery, but it also gave the housewife some authority and a sense of autonomy in a patriarchal society. In addition, contributing to a woman's operation in such a way was the convention of having a male serviceman (kaplcl) in the apartment (Özyeğin 1996). The availability of the serviceman also varied according to socio-economic status of the residences and the building size. Servicemen were often migrants from rural areas. A serviceman offered inexpensive services for maintaining an orderly environment. His duties included running the heating and hot water, collecting the garbage, cleaning the building, keeping the grounds, collecting the maintenance fees and providing security. Significantly, serviceman also helped on a daily basis with the household grocery shopping from the local shops. When people had fewer cars and the majority of women did not drive, having a serviceman was a unique convenience that facilitated the housewife's running of the household. The convention of having a serviceman in a larger and better apartment building is now the standard. His residence is often located in a cramped space on the lower level or in the basement of an apartment, where he lives with his family. His wife usually cleans the apartments as a maid. Together, they represent the lower strata of the social structure and the difference between rural and urban realms.

In retrospect, both a female maid and a male serviceman in the apartment were social actors that (re)configure the middle and upper middle class housewife's gender roles and social power dynamics within a patriarchal structure. Interaction with them made it easy for middle class women to resolve and play out the conflicting gender identities of being a modern housewife. The apartment regulated these subjects and their performances in different spatial contexts (e.g. the servicemen on the lower level, the maid in the kitchen, the middle class housewife in the living room); it also mediated the binaries of rural/urban, traditional/modern and Western/non-Western as a unique space that brought these together. 


\section{Conclusion}

Like her American and European counterparts, a 'modern Turkish woman' in an urban context during the mid-twentieth century was conceptualized as a homemaker - a mother, a wife, a domestic manager and an attractive feminine figure - in charge of the appearance of the contemporary home and representative of the family and the nation on the domestic front. The material quality of her interior space was perceived as an extension of her identity and social status. Simultaneously, it reflected the inhabitants' modernity and civic identity, which were associated with the Western sphere in the post-World War II era. Therefore, housewives in the modern middle strata, as users, consumers, clients and amateur decorators, were active contributors in defining the modern domicile. This active role is important to studies of the history of the built environment and of society at large.

Concrete apartments were viewed as the embodiment of the notions of civilization, Westernization, modernization and urbanization for which the country strived in the bipolar aftermath of the war. They were not only products of new urban conditions that were shaped by economic, social and political constraints, but they also reflected ideas around the family, as they still do. The urban apartment was appropriated for the accommodation of the nuclear family with a comparable 'modern' background in the middle and upper income groups, managed by the housewife. It was a commodity beyond the reach of the lower class, which lived in poorly built houses in low-income neighborhoods or in unplanned squatter houses with inadequate infrastructures. A mass rural population who migrated to urban areas in search of job opportunities developed the latter illegally. In fact, apartments signified the divide between classes before this divide was narrowed much later, when they were built to provide housing for low-income groups and to replace squatter houses. Many apartment buildings of the 1950s and 1960s, including those instigated by the state, embraced modern aesthetics as an expression of modernization.

For the housewife, the apartment signified modernity because it offered comfort, eased household tasks, and, significantly, provided an unmarked domain for the housewife to inscribe her identity. The traditional element of the trousseau (çeyiz), along with women's changing roles as consumers, were instrumental in allowing her to do this, and to thus undo the prescriptive power of architectural design, characterized by transparency, unadorned aesthetics and associated constructions of gender. This suggests that while a woman's performativity as a maker of spaces reinforced her gendered role as a housewife responsible for domestic appearances, it also capacitated transformations or subversions of the local dynamics of patriarchy and everyday experiences of domestic space. A woman's changing role as a modern consumer gave her authority to shape and control her environment. Consequently, the apartment was not only a place where assumed social roles were solidified, but also an arena for women to act out these roles as dynamic figures.

Whereas they eased household drudgery, the architectural design of apartments fell short of meeting functional domestic requirements. The lack of storage space and the large glazed surfaces were cited as major problems. It was up to the housewife to resolve these problems and manage the household. Upper-middle and middle class housewives relied on the services of support staff from the lower strata to do this. Inexpensive domestic assistance became more readily available because of the migration of uneducated rural masses to major cities, as a consequence of the economic dynamics shaped by Cold War politics. The availability of maids and apartment servicemen to perform household chores and their relationship to middle class women in the domestic space was a type of subversion/negotiation that was due to the incompleteness of citational practices. 
These actors helped to resolve conflicting expectations of the modern housewife. The apartment defined their performances and the changes that these performances produced in patriarchal power dynamics and social relations within the domestic space. By bringing together these social actors from different social spaces, the apartment simultaneously set up and mediated the gap between classes. Simultaneously, it embodied the space in between the concepts of modern and traditional, Western and non-Western, urban and rural, and masculine and feminine.

\section{Acknowledgements}

I would like to thank Beverley Mullings and the anonymous reviewers for their valuable suggestions. My heartfelt thanks to the interviewed architects and housewives, who have genuinely opened up their lives and memories.

\section{Notes}

1. Scholars have widely addressed these experiences since the early 1980s. Although studies vary in focus, approach and methods (ranging from psychoanalysis to gender theory), they reflect women's perspectives. My sources include Hayden (1981, 1984, 2000); Matrix (1984); McMurry (1988); Colomina (1991, 1996); Friedman (1992, 1996); Spain (1992); Weisman (1992); Adams (1995); Ross (1995); Sparke (1995); Ockman (1996); Tiersten (1996); Lavin (1999); Walker (2002); and Baydar (2003).

2. Notably, each city had its own time frame in which the idea of the apartment proliferated.

3. The build-sell (yap-sat) model, also seen in other locations, enabled the construction of apartments with little capital. The contractor took property from the owner in exchange for flats. The expenses of the construction were met by pre-selling the apartments. Although this model provided affordable housing in the crowded cities, it also posed some negative effects. In order to maximize profits, historical urban fabric as well as the 1930s and 1940s houses and low-rise apartment buildings were destroyed, the vertical density was increased, and poor construction techniques and materials were used. The latter was especially problematic in a country with serious seismic activity. Architects and historians have criticized the production of 'build-sell' apartments in Turkey, arguing that 'these apartments rarely had any architectural merit' (Kuban 1985, 72).

4. Political, economic and military implementations that reinforced ties with the Western sphere included the following: the Marshall Plan (1947); a bipartite economic treaty with the United States (1948); memberships in the International Bank for Reconstruction and Development (1947); the Organization for European Economic Cooperation (1948); the North Atlantic Treaty Organization (1953); and Turkey's participation in the Korean War (1951).

5. Laura Belmonte $(2003,115,121)$ pointed out that American information officers compared the attractive images of the US housewife to the Soviet woman and man working labor-intensive jobs in selling capitalism oversees. US Information Service materials emphasized that American women could stay at home to raise their children, because men earned higher wages in the United States.

6. The typical American house of the postwar years emerged in suburbia. The availability of inexpensive land, loan programs and transportation were important to the development of the suburbs (Jackson 1985). Levittown (with its Cape Cod houses), built in 1948 by developer William J. Levitt, was an early example of suburbia presented as the American dream that formed the new American landscape. Rosie the Riveter - thrust into heavy manufacturing jobs during the war - returned home (Anderson 1981; Honey 1984; Hayden 1984; Ockman 1996).

7. Ross $(1995,73)$ pointed out that French sociologist Henri Lefebvre developed the concept of 'everyday life' after he overheard his wife's tone of voice praising a certain brand of laundry detergent in their apartment.

8. First domestic washing machines were produced in the 1950s.

9. The distinction between European and American was not readily made by the average person on the street in Turkey during the 1950s. 
10. Significantly, the new regime granted women the right of gender equality, including the right to vote and to stand for election (in 1930 and 1934, respectively).

11. The interviews with housewives indicate the prevalence of this perception. See also Özbay (1990).

12. My comments on this issue are shaped by the interviews.

13. This Turkish cliché, suggesting the emphasis placed on homemaking, was often referred to during the interviews.

14. For this poster and discussion on the conflict between modern interior design and domesticity, see Friedman (1996, 191); Reed (1996, cover).

15. Joel Sanders $(2002,17)$ suggests that reinforcing "the image of the "macho" male architect [as depicted in The Fountainhead ]; simultaneously ... fine-tune[d] a newer cultural cliché - the gay interior decorator.'

16. Hayat (1956-1978) and its forerunner Resimli Hayat (1952-1955) were leading magazines that served to disseminate an ideal image of 'modern' women and lifestyles.

17. For similar experiences of women in the context of postwar apartments in Athens, see Theocharopoulou (2005).

18. Apartment buildings and the advent of apartmentization are usually held responsible for the destruction of the traditional houses and of the historical fabric in Turkey.

19. Such a view may be related to the criticism of Farnsworth House, an architectural icon built by Mies van der Rohe for Edith Farnsworth. The building constitutes an illustrious case in which aesthetic convictions fell short of fully meeting the female client's domestic requirements. See Friedman (1996, 1998).

20. This paradox has been widely addressed by scholars. Architectural historian Reyner Banham (1960) was among the first to question the design motives of modernist masters such as Le Corbusier and Mies van der Rohe and to criticize their functionalist and rationalist claims to design. Witold Rybczynski (1986) questioned the validity of modernist furniture designs as comfortable, rational and functionalist objects of domesticity.

\section{Notes on contributor}

Meltem Ö. Gürel is an Assistant Professor in the Faculty of Art, Design and Architecture at Bilkent University, Ankara. She received her PhD in Architecture from the University of Illinois at UrbanaChampaign, where she taught as an adjunct professor. Gürel has published articles in Journal of Architectural Education, the Journal of Architecture, Journal of Design History, the International Journal of Art \& Design Education and elsewhere. Her research interests include architectural history/theory, cross-cultural histories of modernism with an emphasis on social, gender and cultural studies as they have influenced the built environment in the twentieth century - especially in Turkey, the domestic domain, interior space, and interior design/architecture education.

\section{References}

Abisel, Nilgün. 1984. Türk sinemasında aile. In Türkiye'de ailenin değişimi: Sanat açısından incelemeler, ed. Türköz Erder, 31-46. Ankara: Türk Sosyal Bilimler Derneği.

Adams, Annmarie. 1995. The Eichler home: Intention and experience in postwar suburbia. In Gender, class, and shelter: Perspectives in vernacular architecture V, ed. Elizabeth Collins Cromley and Carter L. Hudgins, 164-78. Knoxville: University of Tennessee Press.

Akcan, Esra. 2001. Amerikanlaşma ve endişe: Istanbul Hilton Oteli. Arredamento Mimarlik, no. $100+41: 112-19$.

Anderson, Karen. 1981. Wartime women: Sex roles, family relations, and the status of women during World War II. Westport, CT: Greenwood Press.

Arat, Yeşim. 1997. The project of modernity and women in Turkey. In Rethinking modernity and the national identity in Turkey, ed. Sibel Bozdoğan and Reşat Kasaba, 95-112. Seattle and London: University of Washington Press.

Ayata, Sencer. 1988. Statü yarışması ve salon kullanımı. Toplum ve Bilim 42: 5-25.

Banham, Reyner. 1960. Theory and design in the first machine age. New York: Praeger.

Baydar, Gülsüm. 2003. Spectral returns of domesticity. Environment and Planning D, Society and Space, 21, no. 1: 27-45. 
Belmonte, Laura. 2003. Selling capitalism: Modernization and U.S. overseas propaganda, 19451959. In Staging growth: Modernization development, and the global cold war, ed. David C. Engerman, Nils Gilman, Mark H. Haefele, and Michael E. Latham, 107-28. Amherst and Boston: University of Massachusetts Press.

Bennett, Katy. 2006. Kitchen drama: Performances, patriarchy and power dynamics in a Dorset farmhouse kitchen. Gender, Place and Culture 13, no. 2: 153-60.

Butler, Judith. 1990. Gender trouble: Feminism and the subversion of identity. New York and London: Routledge.

- 1993. Bodies that matter: On the discursive limits of 'sex'. New York and London: Routledge.

Colomina, Beatriz. 1991. The split wall: Domestic voyeurism. In Sexuality and space, ed. Beatriz Colomina, 73-128. Princeton, NJ: Princeton Architectural Press.

- 1996. Battle lines: E.1027. In The sex of architecture, ed. Diana Agrest, Patricia Conway, and Leslie K. Weisman, 167-82. New York: Harry N. Abrams.

- 1999. The private side of public memory. The Journal of Architecture 4, no. 4: 337-60.

Criss, Nur Bilge. 1993. A facet of Muslim womanhood: The Turkish case. Turkish Review of Middle East Studies 7: 237-59.

Çitçi, Oya. 1974. Kadın ve çalışma. Amme Idaresi Dergisi 7: 45-75.

Ecevit, Yıldız. 1990. Kentsel üretim sürecinde kadın emeğinin konumu ve değişen biçimleri. In Kadın bakış açısından 1980’ler Türkiyesinde kadın, ed. Şirin Tekeli, 105-14. Istanbul: İletişim Yayınc1lik.

Eldem, Sedad H. 1973. Elli yıllık cumhuriyet mimarlı̆̆ı. Mimarlık, nos. 11-12: 5-11.

Friedan, Betty. 1963. The feminine mystique. New York: Dell Publishing.

Friedman, Alice T. 1992. Architecture, authority, and the female gaze: Planning and representation in the early modern country house. Assemblage 18: 40-61.

. 1996. Domestic differences: Edith Farnsworth, Mies van der Rohe, and gendered body. In Not at home: The suppression of domesticity in modern art and architecture, ed. Christopher Reed, 179-92. London: Thames and Hudson.

- 1998. Women and the making of the modern house: A social and architectural history. New York: Harry N. Abrams.

Gregson, Nicky, and Gillian Rose. 2000. Taking Butler elsewhere: Performativities, spatialities and subjectivities. Environment and Planning D: Society and Space 18: 433-52.

Gürel, Meltem Ö. 2008. Bathroom as a modern space. Journal of Architecture 13, no. 3: 215-33. 2009. Consumption of modern furniture as a strategy of distinction in Turkey. Journal of Design History 22, no. 1: 47-67.

Hayden, Dolores. 1981. The grand domestic revolution: A history of feminist designs for American homes, neighborhoods, and cities. Cambridge, MA: MIT Press.

- 1984, 2002. Redesigning the American dream: Gender housing and family life. New York and London: W.W. Norton \& Company.

- 2000. What would a non-sexist city be like? Speculations on housing, urban design and human work. In Gender, space, architecture, ed. Jane Rendell, Barbara Penner, and Iain Borden, 266-81. London: Routledge.

Heynen, Hilde. 2005. Modernity and domesticity: Tensions and contradictions. In Negotiating domesticity: Spatial productions of gender in modern architecture, ed. Hilde Heynen and Gülsüm Baydar, 1-29. New York: Routledge.

Honey, Maureen. 1984. Creating Rosie the Riveter: Class, gender, and propaganda during World War II. Amherst: University of Massachusetts Press.

Jackson, Kenneth T. 1985. Crabgrass frontier: The suburbanization of the United States. New York: Oxford University Press.

Johnson, Louise C. 2006. Browsing the modern kitchen - a feast of gender, place and culture (Part 1). Gender, Place and Culture 13, no. 2: 123-32.

Kandiyoti, Deniz. 1982. Urban change and women's roles in Turkey: An overview and evaluation. In Sex roles, family, and community in Turkey, ed. Çiğdem Kağıtçıbaşı, 101-20. Bloomington, IN: Indiana University Turkish Studies.

Kennedy, Nilgün Fehim. 1999. A comparison between women living in traditional Turkish houses and women living in apartments in historical context. MS thesis, METU.

Kıray, Mübeccel. 1982. Apartmanlaşma ve modern orta tabakalar. In Toplum Bilim Yazıları, 385-7. Ankara: Gazi Üniversitesi. 
Komarovsky, Mirra. 1964. Blue-collar marriage. In collaboration with Jane H. Philips. New York: Random House.

Kuban, Doğan. 1985. A survey of modern Turkish architecture. In Architecture in continuity building in the Islamic world, ed. Sherban Cantacuzino, 64-75. Aperture Islamic Publications.

Kuyaş, Nilüfer F. 1982. The effects of female labor on power relations in the urban Turkish family. In Sex roles, family, \& community in Turkey, ed. Çiğdem Kağıtçıbaşı, 181-205. Bloomington, IN: Indiana University Turkish Studies.

Lavin, Sylvia. 1999. Open the box: Richard Neutra and the psychology of the domestic environment. Assemblage 40: 6-25.

Le Corbusier. 1923, 1986. Towards a new architecture. New York: Dover.

- 1949. Ufki şehir, şakuli şehir. Arkitekt, nos. 211-214: 162-5.

Lefebvre, Henri. 1991. The production of space. Oxford: Blackwell.

Matrix. 1984. Making space: Women and the man-made environment. London: Pluto Press.

May, Elaine Tyler. 1988. Homeward bound: American families in the cold war era. New York: Basic Books.

McLeod, Mary. 1994. Undressing architecture: Fashion, gender, and modernity. In Architecture in fashion, ed. Deborah Fausch, 38-123. New York: Princeton Architectural Press.

McMurry, Sally. 1988. Women in the American vernacular landscape. Material Culture 20: 33-49.

Oakley, Ann. 1976. Housewife. Harmondsworth: Penguin Books.

Ockman, Joan. 1996. Mirror images: Technology, consumption, and representation of gender in American architecture since World War II. In Sex of architecture, ed. Diana Agrest, Patricia Conway, and Leslie K. Weisman, 191-210. New York: Harry N. Abrams.

Özbay, Ferhunde. 1990. Kadınların eviçi ev dışı uğraşlarındaki değişme. In Kadın bakış açısından 1980'ler Türkiyesinde kadın, ed. Şirin Tekeli, 117-44. Istanbul: İletişim Yayıncılık.

- 1996. Houses, wives and housewives. In Housing question of the others, ed. Emine M. Komut, 49-59. Ankara: Chamber of Architects.

Özyeğin, Gül. 1996. The view from downstairs: Place and stigma in the lives of caretakers' wives. In Housing question of the others, ed. Emine M. Komut, 140-54. Ankara: Chamber of Architects.

Rainwater, Lee, Richard P. Coleman, and Gerald Handel. 1959. Workingman's wife. New York: Arno Press.

Rand, Ayn. 1943. The fountainhead. Indianapolis and New York: The Bobbs-Merrill Company.

Reed, Christopher, ed. 1996. Not at home: The suppression of domesticity in modern art and architecture. London: Thames and Hudson.

Ross, Kristin. 1995. Fast cars, clean bodies: Decolonization and the reordering of French culture. Cambridge, MA: MIT Press.

Rybczynski, Witold. 1986. Home: A short history of an idea. New York: Viking.

Saarikangas, Kirsi. 2006. Displays of the everyday: Relations between gender and the visibility of domestic work in the modern Finnish kitchen from the 1930s to the 1950s. Gender, Place and Culture 13, no. 2: 161-72.

Sanders, Joel. 2002. Curtain wars. Harvard Design Magazine 16: 14-20.

Spain, Daphne. 1992. Gendered spaces. Chapel Hill: University of North Carolina Press.

Sparke, Penny. 1995. As long as it's pink: The sexual politics of taste. London: Pandora.

. 2004. Studying the modern home. The Journal of Architecture 9, no. 4: 413-7.

Supski, Sian. 2006. 'It was another skin': The kitchen as home for Australian post-war immigrant women. Gender, Place and Culture 13, no. 2: 133-41.

Şenyapıl1, Tansı. 1996. New problems/old solutions: A look at the gecekondu in the urban space. In Housing and settlement in Anatolia - A historical perspective, ed. Y1ldız Sey, 345-54. Istanbul: The Economic and Social History of Turkey.

Tekeli, İlhan. 1984. The social context of the development of architecture in Turkey. In Modern Turkish architecture, ed. Renata Holod and Ahmet Evin, 9-33. Philadelphia: University of Pennsylvania Press.

Theocharopoulou, Ioanna. 2005. The housewife, the builder, and the desire for a polykatoikia apartment in postwar Athens. In Negotiating domesticity: Spatial productions of gender in modern architecture, ed. Hilde Heynen and Gülsüm Baydar, 65-82. New York: Routledge.

Tiersten, Lisa. 1996. The chic interior and the feminine modern: Home decorating as high art in turnof-the-century Paris. In Not at home: The suppression of domesticity in modern art and architecture, ed. Christopher Reed, 18-32. London: Thames and Hudson.

Walker, Lynne. 2002. Home making: An architectural perspective. Signs 27, no. 3: 823-35. 
Watkins, Helen. 2006. Beauty queen, bulletin board and browser: Rescripting the refrigerator. Gender, Place and Culture 13, no. 2: 143-52.

Weisman, Leslie K. 1992. Discrimination by design. Urbana and Chicago, IL: University of Illinois Press.

Wigley, Mark. 1991. Untitled: The housing of gender. In Sexuality and space, ed. Beatriz Colomina, 326-90. Princeton, NJ: Princeton Architectural Press.

— 1993. White-out: Fashioning the modern [part 2]. Assemblage 22: 6-49.

1995. White walls, designer dresses. Cambridge, MA: MIT.

1998. The fashioning of modern architecture. Rassegna 20, no. 73: 30-50.

Young, Michael, and Peter Willmott. 1957. Family and kinship in East London. Baltimore: Penguin Books.

\section{ABSTRACT TRANSLATION \\ Definir y vivir fuera del interior: el departamento 'moderno' y el ama de casa 'urbana' en Turquía durante las décadas de 1950 y 1960}

Este estudio investiga la interacción de las identidades y desempeños generizados de las mujeres en el estrato medio moderno con el nuevo departamento, mientras complejiza los límites entre los discursos legitimadores de la arquitectura moderna y las ideas alrededor de la feminidad, durante las décadas de 1950 y 1960 en Turquía. Conceptualiza los lugares domésticos como el espacio del habitante, donde los roles de género son formados y desempeñados. Basándome en investigación sobre la construcción de posguerra de las identidades de las mujeres y sus diversas ideas del espacio femenino en un contexto global, examino cómo el departamento fue un lugar para la mujer, quienes fueron conceptualizadas como amas de casa felices y occidentales en el contexto de la geopolítica de la guerra fría. El estudio pondera formas en las que las mujeres negociaron/subvirtieron expectativas en conflicto del ama de casa moderna. El departamento medió entre poderosos discursos sobre estructuras de patriarcado e identidades, y simultáneamente permitía a las mujeres definir y vivir fuera del domicilio moderno como agentes activos. Encarnó el espacio intermedio entre los conceptos de lo moderno y lo tradicional, occidental y no occidental, urbano y rural, y masculino y femenino.

Palabras clave: ama de casa; espacio doméstico; desempeñabilidad; arquitectura moderna; departamento; Turquía

\section{在本質之外書界與生活：1950年到1960年代土耳其的「現代」公寓與「都市」家庭主婦}

本研究探討在1950到1960年代的土耳其，擁有新公寓的現代中間階層女性之性別認同與展演之間 的互動關係。在此時期, 有關女性氣質的現代建築與思維之合法性論述之間的複雜界線。本文將家 庭的前提概念化為居住者的空間, 性別的角色在其中被形構與展演出來。透過對於戰後女性認同的 建構, 以及在全球脈絡下女性化空間多樣性概念的探討, 我檢視了對於在冷戰時期被地綠政治中的 「西方」概念化為「快樂家庭主婦」的女性而言, 公寓是什麼樣的空間。本研究仔細分析, 在對於 現代家庭主婦的角色期望之下, 女性透過什麼樣的方式來與之協商與衝撞。公寓表現了家父長制與 認同結構的權力論述, 但同時也允許女性做為一主要能動者去畫界並來往於于現代居所之範圍。此 點體現在現代與傳統，西方與非西方，都市與農村，以及陽剛與陰柔概念之間的仲介空間。

鬬鍵字: 家庭主婦，居住空間，展演，現代建築，公寓，土耳其 